\title{
Evaluation of Heavy Metals in Peppers Sold Along Papa- Abeokuta Highways, Ogun State, Southwest, Nigeria
}

\author{
${ }^{1}$ MAKANJUOLA, Olakunle Moses, ${ }^{2}$ OSINFADE, Bashiru Gboolahan \\ ${ }^{1}$ Department of Food Technology, Federal Polytechnic, Ilaro, Ogun State, Nigeria \\ ${ }^{2}$ Department of Science Laboratory Technology, Federal Polytechnic Ilaro, Ogun State, Nigeria
}

\begin{abstract}
The evaluation of heavy metal concentrations in five pepper samples sold along Papa-Abeokuta highways, Ogun State, South West Nigeria was investigated in this present work using standard methods. The heavy metals viz. Lead (Pb), Cadmium (Cd), Manganese (Mn), Copper ( $\mathrm{Cu}$ ), Mercury ( $\mathrm{Hg}$ ) and Zinc ( $\mathrm{Zn}$ ) were determined using Atomic Absorption Spectrophometry Method. The results of the analysis showed that lead $(\mathrm{Pb})$ ranged from $0.02 \mathrm{mg} / 100 \mathrm{~g}$ to $0.07 \mathrm{mg} / 100 \mathrm{~g}$; Cadmium varied from $0.00 \mathrm{mg} / 100 \mathrm{~g}$ to $0.01 \mathrm{mg} / 100 \mathrm{~g}$; while Manganese (Mn) ranged from $0.02 \mathrm{mg} / 100 \mathrm{~g}$ to $0.05 \mathrm{mg} / 100 \mathrm{~g}$; The level of copper $(\mathrm{Cu})$ as shown by the result are; $0.31 \mathrm{mg} / 100 \mathrm{~g} ; 0.57 \mathrm{mg} / 100 \mathrm{~g} ; 0.60 \mathrm{mg} / 100 \mathrm{~g} ; 0.43 \mathrm{mg} / 100 \mathrm{~g}$ and $0.73 \mathrm{mg} / 100 \mathrm{~g}$ respectively for all the five pepper samples. Mercury, though in negligible amount has highest concentration of $0.01 \mathrm{mg} / 100 \mathrm{~g}$ while Zinc $\mathrm{Zn}$ ) varied from $0.50 \mathrm{mg} / 100 \mathrm{~g}$ to $0.70 \mathrm{mg} / 100 \mathrm{~g}$. The results generally revealed that level of contamination by these heavy metals on the pepper samples were very low when compared to the permissible limits stipulated by FAO/WHO (2003).
\end{abstract}

Keywords: Heavy metal, Concentration, Pollution, Peppers, Evaluation

\section{INTRODUCTION}

A heavy metal is a member of a loosely subset of element that exhibits metallic property. It mainly includes the transition metals, some metalloids, lanthanides and actinides. Heavy metal occurs naturally in the ecosystem with large variation in concentration. In modern times, anthropogenic source of heavy metals, that is pollution have been introduced to the ecosystem (1). Heavy metal toxicity can result in damaged or reduced mental and central nervous function, lower energy level and damage to blood composition, lungs, kidney, liver and other vital organs. Long term exposure may result to slowly progressing physical, muscular and neurological degenerative process that mimic Alzheimer disease, Parkinson's disease, muscular dystrophy and multiple sclerosis. Allergies are not uncommon and repeated long term contract with some metal (or their compounds) may cause cancer (2). The presence of heavy metals in food substance constitutes serious health hazards, developing in their relative level (3).

Peppers are medicinal plants that are consumed worldwide for the treatment of several diseases. With the current emphasis on eating more healthy diet that are low in fat and salt, people are turning to various herbs and spices that are used to enhance and flavor their food (4). The problem of food contamination by toxic metal ions is receiving a global attention. It also remains a fact that the problems of food contamination by toxic metal worsen as daily traffic increases (3). Therefore, this present work aims at evaluating the effect of traffic exhaust and gaseous industrial wastes on the concentration of heavy metals in peppers sold along Papa-Abeokuta major highways vis a vis their possible level in relation to the health of people consuming these peppers

\section{Materials AND Methods}

Source of materials: Samples of pepper viz Tomato, Chilli pepper, Bell pepper, Hot pepper and Red pepper were purchased at various point of sales (Five major points) where traffic are high along Papa- 
Abeokuta highway, Ogun State, Southwest, Nigeria. The samples were placed in Polythene bags and stored in cool dry place prior to analyses.

\subsection{Methods}

\subsubsection{Analytical Procedure}

The pepper samples were properly washed with clean portable water and oven dried at $60^{\circ} \mathrm{C}$ for 12 hours. The dried samples were ground to fine powder using laboratory mortar and pestle.

The determination of heavy metal concentrations was carried out using wet digestion method as described by Jone and Case (1990) (5). O.5g of each pepper sample was placed in 100ml beaker after which $3.5 \mathrm{ml}$ of $30 \% \mathrm{H}_{2} \mathrm{O}_{2}, 3 \mathrm{ml} \mathrm{H}_{2} \mathrm{SO}_{4}, 0.5 \mathrm{ml} \mathrm{HNO}_{3}$ and $1 \mathrm{ml} \mathrm{HCLO} 3$ were added. The content in each beaker was first heated to $100^{\circ} \mathrm{C}$ and gradually increased to $250^{\circ} \mathrm{C}$, left at this temperature for 30 minutes. Each beaker and its content were then allowed to cool and an additional $1 \mathrm{ml}$ of $30 \% \mathrm{H}_{2} \mathrm{O}_{2}$ added to the digestion mixture and reheated. The digestion process was repeated until a clear solution was obtained in each case (6). The clear solution was transferred to $50 \mathrm{ml}$ volumetric flask, made up to mark with distilled water. Blank solution was also prepared. Standard solution for each element under investigation was prepared and used for calibration. Measurement for each heavy metal was carried out using Atomic Absorption Spectrophotometer with double beam and deuterium background correction (Perkin Elmer Model 900).

\section{RESUlts AND DisCUSSIONS}

\subsection{Result}

Table showing the concentration of heavy metal in pepper $(\mathrm{mg} / 100 \mathrm{~g})$ sold along Papa-Abeokuta, Ogun State, South West, Nigeria

\begin{tabular}{|l|l|l|l|l|l|l|}
\hline Sample & $\mathrm{Pb}$ & $\mathrm{Cd}$ & $\mathrm{Mn}$ & $\mathrm{Cu}$ & $\mathrm{Hg}$ & $\mathrm{Zn}$ \\
\hline $\mathrm{A}$ & $0.02 \pm 0.01$ & $0.00 \pm 0.00$ & $0.03 \pm 0.01$ & $0.32 \pm 0.24$ & $0.00 \pm 0.00$ & $0.57 \pm 0.06$ \\
\hline $\mathrm{B}$ & $0.05 \pm 0.00$ & $0.01 \pm 0.01$ & $0.05 \pm 0.01$ & $0.57 \pm 0.12$ & $0.00 \pm 0.00$ & $0.70 \pm 0.00$ \\
\hline $\mathrm{C}$ & $0.03 \pm 0.01$ & $0.01 \pm 0.01$ & $0.03 \pm 0.01$ & $0.60 \pm 0.10$ & $0.01 \pm 0.01$ & $0.57 \pm 0.06$ \\
\hline $\mathrm{D}$ & $0.05 \pm 0.01$ & $0.01 \pm 0.00$ & $0.02 \pm 0.01$ & $0.43 \pm 0.06$ & $0.00 \pm 0.01$ & $0.50 \pm 0.00$ \\
\hline $\mathrm{E}$ & $0.07 \pm 0.01$ & $0.02 \pm 0.01$ & $0.04 \pm 0.01$ & $0.73 \pm 0.06$ & $0.01 \pm 0.00$ & $0.60 \pm 0.00$ \\
\hline
\end{tabular}

Key: $A \rightarrow$ Chilli pepper, $B \rightarrow$ Bell pepper, $C \rightarrow$ Tomatoes, $D \rightarrow$ Hot pepper, $E \rightarrow$ Red pepper

\subsection{Discussion}

Table 1 shows the concentration of some heavy metals $(\mathrm{mg} / 100 \mathrm{~g})$ in pepper sold along papaAbeokuta road Ogun State, South West, Nigeria. All the five pepper samples were analyzed for Lead $(\mathrm{Pb})$, Cadmium $(\mathrm{Cd})$, Manganese $(\mathrm{Mn})$, Copper $(\mathrm{Cu})$, Mercury $(\mathrm{Hg})$ and Zinc $(\mathrm{Zn})$. As revealed from the table, Zinc has the highest values $(0.70 \mathrm{mg} / 100 \mathrm{~g}$ ) obtained from sample B (Bell pepper) while the presence of Mercury $(\mathrm{Hg})$ and Cadmium were at almost nil in some samples, for example in chili pepper, bell pepper and hot pepper. The concentration of Zinc ranged from $0.50 \mathrm{mg} / 100 \mathrm{~g}$ to $0.70 \mathrm{mg} / 100 \mathrm{~g}$ for the five samples under consideration. Zinc plays important roles in growth and development in human $(7,8)$. It is known to be an important trace element as a cofactor for insulin $(9)$. Whereas, the recommended daily. Dietary intake of zinc stands at about $15 \mathrm{mg}$ (9), its accumulation over time can pose possible health risk to consumers. The concentrations of lead $(\mathrm{Pb})$ for the samples were $0.02 \mathrm{mg} / 100 \mathrm{~g} ; 0.05 \mathrm{mg} / 100 \mathrm{~g} ; 0.03 \mathrm{mg} / 100 \mathrm{~g} ; 0.05 \mathrm{mg} / 100 \mathrm{~g}$; and $0.07 \mathrm{mg} / 100 \mathrm{~g}$ respectively. Lead has been shown to have toxic impact on a variety of metabolic process essential to plant growth and development including photosynthesis, transpiration, DNA synthesis and mitotic activity $(9,10)$. The level of lead $(\mathrm{Pb})$ in the pepper samples were very low, even with $0.07 \mathrm{mg} / 100 \mathrm{~g}$ obtained from hot pepper when compared to the permissible. Limit required in spices $(0.3 \mathrm{mg} / \mathrm{kg})$ by the FAO/WHO (11).According to literature, $(9,12)$, cadmium is toxic to human even at low concentration. It is reported to cause osteomalacia. It badly affect the cardio vascular system and kidney functioning. The concentration of cadmium in all the five pepper samples varied from $0.00 \mathrm{mg} / 100 \mathrm{~g}$ to $0.02 \mathrm{mg} / 100 \mathrm{~g}$. This level tend to pose no health risk to the consumer.

Manganese as revealed by the analytical result was found to range from $0.02 \mathrm{mg} / 100 \mathrm{~g}$ to $0.05 \mathrm{mg} / 100 \mathrm{~g}$. Manganese $(\mathrm{Mn})$ is one of the major minerals, which is related to the carbohydrate and fat metabolism. The major source of manganese $(\mathrm{Mn})$ in soil are; fertilizers, sewage. Sludge and 
ferrous smelters. (9). The amount of manganese obtained from this work is extremely low when compared with daily dietary intake of $2.5 \mathrm{mg}$ considered to be suitable for human adult as reported in a previous work (9). The concentrations of copper $(\mathrm{Cu})$ were $0.32 \mathrm{mg} / 100 \mathrm{~g} ; 0.57 \mathrm{mg} / 100 \mathrm{~g}$; $0.60 \mathrm{mg} / 100 \mathrm{~g} ; 0.43 \mathrm{mg} / 100 \mathrm{~g}$ and $0.73 \mathrm{mg} / 100 \mathrm{~g}$ for all the five pepper samples. Copper helps in iron metabolism by helping in oxygen transport as well as utilization and absorption of iron in humans (13). According to literature (14), copper is an essential element in trace amount, but can be toxic at excess level. Copper can result in a tendency for hyperactivity in austistic children. An excess of copper can cause oily skin loss of skin tone (due to ability to block vitamin C) and cause a dark pigment on skin specially, around face. It can attribute to hair loss especially in women $(14,15)$. Also, The levels of copper in all the pepper samples were below the FAO/WHO (11-) perishable level in plants. Highest concentration of $0.01 \mathrm{mg} / 100 \mathrm{~g}$ mercury was obtained from two of the pepper samples and therefore poses no health risk to consumers when consumed. The mean values for the heavy metals determined in pepper samples with their local names are as shown in figures 1-6.

\section{Conclusion}

This study has shown that samples of pepper sold along papa-Abeokuta high ways are not contaminated with heavy metals evaluated, though the influx of environmental pollution basically from vehicle exhaust and other gaseous air pollutant could be high. However, low level of heavy metals obtained can also be linked to the fact that most of these pepper displayed for sales along these major routes are usually covered with tarpaulin and thick polyethylene bags.

\section{REFERENCES}

[1] John, H.D (2002): Heavy metals, a meaningless term (IUPAC) Technical report. Pure and Applied Chemistry. 74: 793-807

[2] Michael, H (2010): Encyclopedia of Health National Council for Science and the Environment. Washington D.C. Article 150368:1

[3] Luke, J.A (1997): Effect of Fluoride on the physiology of the pineal gland. A dissertation submitted to the school of Biological Sciences, University of Survey. 1-9; 51-53

[4] Culinary Herbs: (http://www.vegetarian-nutritioninfo/vn/herb-spicephp.acessed20/01/2009.

[5] Jones, J.B and Case, V.W (1990): Sampling, handling and analyzing plant tissue sample. Soil testing and plant analysis, SSSA Inc. Madison. Southern Cooperative Series Bulletin \#368: 1121.

[6] Kaira, R.P (1998): Hand book of reference methods for plant analysis. CRC Press: 57

[7] Colak, H, Soylak, M and Turkuglu, O (2005): Determination of trace metals contents of various herbal and fruit teas produced and marketed from Turkey. Trace Elem. Electrolytes, 22: 192-195.

[8] Darko, B;Atim, I and Voegborlo, R.B (2014): Detection of Heavy metal content of pepper and seasonings on the Ghanaian markets. African Journal of Food Science. 8 (1): 14-19.

[9] Kimani, M.Z, Mohiuddin, S, Naz, F, Naqvi, I.I and Zahir, E (2011); Detection of heavy metals in pepper. J. Basic and Applied Science. 7(2): 89-95

[10] Wierzbicka, M (1999): The effect of load on the cell cycle in the root meristem of Allium copa L. Protoplasm. 207: 186-194

[11] FAO/WHO (2003): Sixty first report of the Joint FAO/WHO Expert Committee on Food Additives and Evaluation of certain additive and contaminants. Codex stand. 230-2001, Rev, 12003, Rome.

[12] Shumacher, M, Bosque, M.A, Domingo, J.L and Carbella, J. (1991). Bull Environ Toxic. 46:320

[13] Ozpelik, D, Toplan, S, Ozdemir, S and Akyolcu, M.C (2002): Effect of excessive copper intake on hematological and hemorheological parameters. Biomed. Life Sci: 88(1): 35-42

[14] Mubeen, H, Naeem, I,Toskeen, A and saddiq, Z (2009): Investigation of Heavy Metals in Commercial spices Brands. New York Science Journal. 2(5): 20-26.

[15] Gupta, U (1975): Copper in the Environment. J.O. Nriagu ed. 255, John Wiley and Sons Inc. New York. 